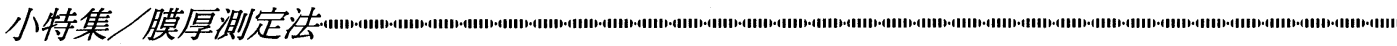

\title{
渦電流式膜厚測定
}

結 城 英 恭*

\section{Measurement of Coating Thickness by Eddy Current Equipment}

\section{Hideyasu YUUKI*}

Key Words : Thickness Measurement, Coating Thickness, Eddy Current Equipment

渦電流式膜厚計は非破壊計測が可能で, しかも $0.1 \mu \mathrm{m}$ の分解能をもっているため, アルマイト 被膜を中心に品質管理から研究開発用まで広く用 いられている。

\section{1. 原 理}

渦電流式を原理とした膜厚計は, アルミニウム, 銅，真ちゅう，オーステナイト系のステンレス等 の良好な導電材料に施された塗装, 樹脂, 酸化物 等の絶縁材料の膜厚測定に多く用いられている。

測定原理は，図1のようにフェライト材料にコ イルを巻き，それに高周波電流を流して導電材料 に近づけるとその導電材料の表面に渦電流が流れ る。この渦電流は, 図 2 のようにコイル之導電材 料との距離 $(D)$ にほぼ比例的に変化する。これ をコイル側から論じると，コイルのインダクタン スが変化することになる。従って，コイルと導電 材料の中間に存在する材料, 即ち皮膜が絶縁材料 であれば図 2 と同様な関係が成り立ち，インダク タンスの変化量と膜厚との関係を予め求めておけ ば，非破壊式膜厚計として用いることができる。

では，実際に渦電流式膜厚計を設計する際に留 意する点はどんなことであろうか。渦電流を発生 させるには，周波数が高いほど有利であるが，必 要以上に高くすると, 電子回路, センサー（コイ ル部）の周囲温度やロケーションによる不安定

*(株)ケッ科学研究所（宁143 東京都大田区南馬込 1-8-1, 03-776-1111)

Ket Electric Laboratory (8-1, Minami-magome 1 -chome, Ohta-ku, Tokyo 143)

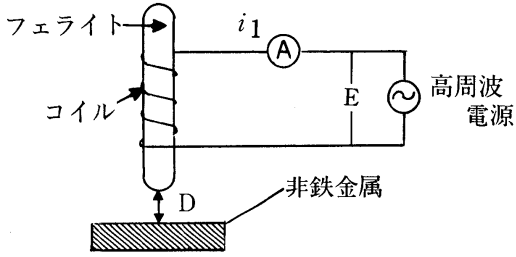

図 1 渦電流式膜厚計の测定原理

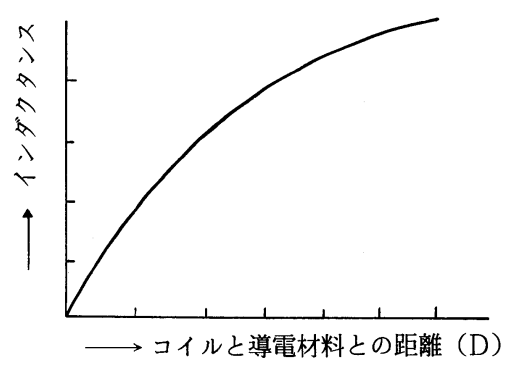

図 2 インダクタンスの変化量と膜厚の関係

さが問題となる。一般的には， 1 〜 $10 \mathrm{MHz}$ 程度 の周波数帯が多く用いられている。また最近では インダクタンスの計測には, 発振回路方式が最む 多く用いられているようである。この方式は，構 成部品点数が少なく，低価格で優れた安定性をもっ ている。

渦電流式膜厚計であう一つ大事なことは, セン サーの先端部分の材料である。センサーの先端部 は, 測定対象物に常に接しているので, 機械的に は, 耐摩耗性, 耐衝撃性が, また電気的には優れ た絶縁性が要求される。これらの条件を満足する 材料として, 人工ルビーやサファイアが用いられ 
ている。

以上, 渦電流式膜厚計の性能を左右するポイン 卜をまとめてみると, 使用する周波数, インダク タンス計測回路, センサー部の機械的強度そして 電気的絶縁性等が挙げられる。膜厚計は，これら の要素がそのコストに応じてバランス良く使われ ていることが大事である。

\section{2. 特 徵}

(1) 非破壊計測ができる。

（2）非破壊計測が可能であることから，測定回 数を多くとれるので, 測定対象物の特定部位 に限らず全体の膜厚を簡単に把握することが できる。現在では，統計計算機能が設けられ ているものも用意されている。

（3）小型軽量である。本体重量が $500 \mathrm{~g}$ 以下の あのあある。

（4）取扱いが簡単で，足場の悪い現場での計測 あ可能である。

（5）繰り返し精度が良く，個人差が生じない。

(6) 安価である。

\section{3 . 得意, 不得意とする被測定検体}

渦電流の流れ具合は，素地材質に最も強く影響 されるが, 素地自身の厚さや素地表面粗さにも関 係する。従って，アルミサッシのアルマイト皮膜 測定のように，素地厚さが確保され，かつ素地面 が比較的平滑なものでは, 精度よく測定できる。 ところが，ブラスト処理された粗い素地面をむつ 材料や，アルミ缶のように素地自身の厚さが 100 $\mu \mathrm{m}$ 程度の材料では, 测定器本来の精度を求め ることは難しい。もっとも, 素地厚さや表面粗さ が，渦電流に影響を与えないような一様の条件を もっていれば，それなりにキャリブレーションを 行って測定することができるが，実際には条件が 整っていない。

\section{4. 標準板についての留意点}

渦電流式膜厚計には，キャリブレーションのた
めの標準板が必ず装備されている。キャリブレー ションは, 既知の厚さの標準板を用いて行われる ので, 標準板の精度が膜厚計の精度に直接係わる ことになる。従って, 標準板は, 経時的に厚さが 変わらず物理的, 化学的強度が優れているものが 要求される。もしも, 使用過程で, 傷ついたり, 折れ曲がったりした場合は，新しいものと交換し て常に正しいキャリブレーションが行えるように, そのメンテナンスに留意する必要がある。

ここに標準板として必要条件を具体的に列記す る。

(1) 表記されている厚さが正確である。

(2) 絶縁性に優れている。

（3）センサーを押し当ててあへこみ難い。

（4）厚さが，温度等の周囲環境に影響されない。

(5) 厚さが，経時的に変化しない。

(6) 部位による厚さのバラッキがない。 以上の条件を満たす材料として, 現在のところポ リエステル・フィルムが多用されている。

\section{5. キャリブレーション}

渦電流式膜厚計は, 比較測定であるため, 測定 素材ごとに使用前にキャリブレーションをする必 要がある。ただし，最近，マイコンを備えたもの が市販されるようになり，キャリブレーションに よって得られた検量線を記憶することができ，同 一素材であれば，測定ごとにキャリブレーション をする必要がなく大変使いやすくなっている。キャ リブレーションは次の点に留意する。

（1）測定対象物之同じ材質, 形状の素地（原則 として平滑な面をむったもの）を用いる。

(2) どうしても標準板自身に部位による厚さの 違いがあるので，それによる誤差を避けるた

表 1 膜厚の測定範囲とキャブレーション

\begin{tabular}{c|cc}
\hline 測定範囲 & 標 準 板 4 点 調 整 \\
\hline $0 \sim 100 \mu \mathrm{m}$ & ゼロ板, $10 \mu \mathrm{m}, \quad 40 \mu \mathrm{m}, 100 \mu \mathrm{m}$ \\
\hline $100 \sim 400 \mu \mathrm{m}$ & ゼロ板, $40 \mu \mathrm{m}, 100 \mu \mathrm{m}, 400 \mu \mathrm{m}$ \\
\hline $400 \sim 800 \mu \mathrm{m}$ & ゼロ板, $100 \mu \mathrm{m}, 400 \mu \mathrm{m}, 750 \mu \mathrm{m}$ \\
\hline
\end{tabular}




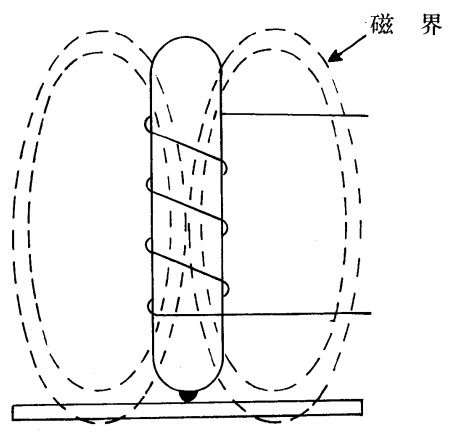

図4 高周波磁界の分布

め，多くの部位を測定し，その平均值を採用 するようにする。

（3）测定対象物の膜厚の測定範囲によって，方 法を分ける。具体的には，次のような方法が 最適である（図 3 ）。

\section{6. 測定時の留意点}

\section{1 素地の厚さによる影響}

センサーから発する高周波磁界は, 図 4 のよう に分布している。この磁界が素地厚を通過しなけ れば，その範囲内で厚さが異なっても測定值に影 響することはないが，通過するとなると問題があ る。具体的には，素材が薄くかつその素材の厚さ にバラッキがあると，渦電流変化は膜厚のみなら ず厚さにも影響され，その分が俁差となる。これ を避けるための方法として次の点に注意する。

（1）磁界が通過する材料で，その厚さが一定の あのでは，十分厚さのある機械的強度のしっ かりした絶縁材料（例えばアクリル）の上で 測定する。

（2）素材が薄く厚さのバラッキがあるあのは， キャリブレーション，計測時とあに，そのあ のと同じ材料で厚さが十分あるあのを敷いて 測定するとよい（図 5 ）。

\section{2 素地の材質による影響}

原則的には，素地の導電率の違いによって，測 定值に差がでるので，測定対象と同様な材料でキャ リブレーションをしなければならない（図6）。

\section{3 素地の面積による影響}

小さな部品や形がさまざまな部品を測定するに

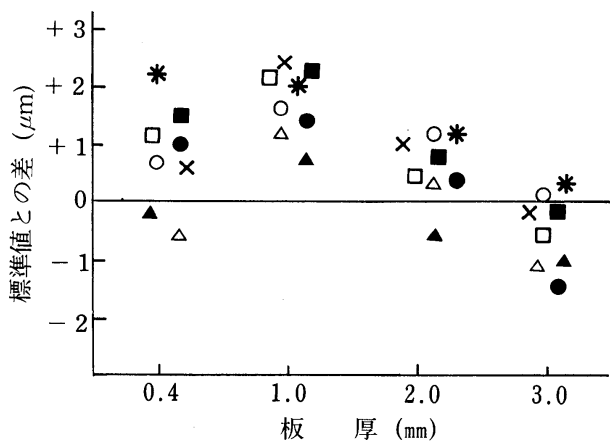

図 5 素地の厚さによる影響

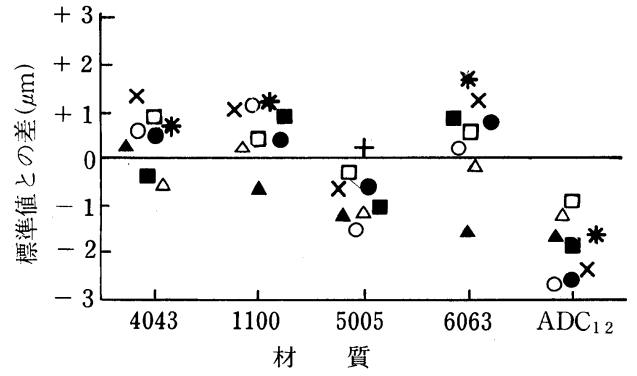

図 6 素地の材質による影響

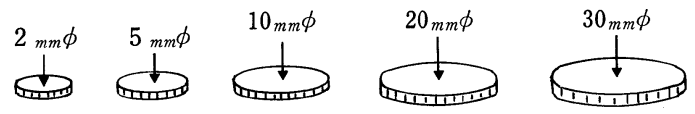

図 7 試験片

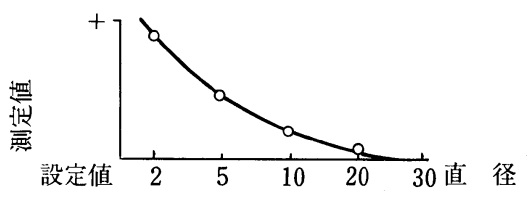

図 8 測定面積の影響

は，その面積を考慮しなければならない。一点接 触式センサーは，点接触なので小さな部位も何の 考慮もせずに測定できると考えがちだが，実際セ ンサーから発する磁界は接点の数百倍以上にもな る。そこで，測定対象物の面積が，膜厚測定によ゙ の程度影響するか試験してみた。

試験方法は，一枚の平滑な金属板（純度の高い アルミニゥムか銅が良い）から一連の異なった直 径の円板を打ち抜く。一番径の大きい円板でキャ 


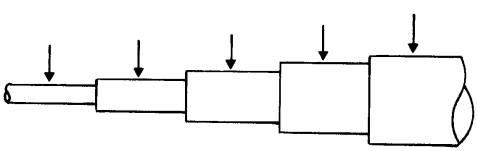

図 9 测定形状

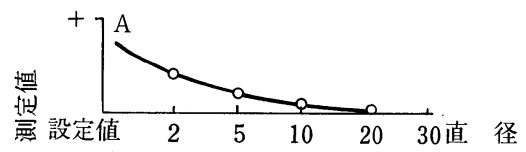

図10 测定形状 (直径) の影響

リブレーションをとり，順次径の小さな円板を測 定する。このような測定面積による誤差を避ける ためには，測定対象と同様な形状の材料でキャリ ブレーションすることの他はない（図 7，8）。

\section{4 丸棒, パイプ状の材料の直径による影響} 測定対象物は平面とは限らず，丸棒やパイプそ して自動車のボディのようにわん曲したあのああ る。丸棒の直径による誤差がごの程度か, 一つの 材料を図 9 のように機械加工して調查してみた。 方法は前項 6.3 之同様に最大径の所でキャリブレー ションをした後, 径の大きなものから順次測定し た。ここであ直径によって誤差が生じる。これの 解決方法は前記6.3と同様である（図10）。

\section{7. 表示・記録方式}

最近では，マイコンやデジタル技術の進歩によ り, 安価で, 小型・軽量のデジタル式ディスプレ イが，膜厚計に多く採用されている。デジタル表 示器は, 液晶 (LCD)または発光ダイオード（LE
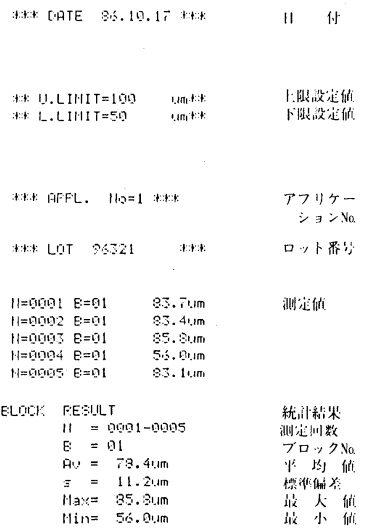

図11 印字例

D)のあのが主流で用途によって使い分けられて いるが，消費電力が少ないLCD 表示が多く使わ れている。また膜厚計自身が多機能になったため, 表示内容む単に膜厚値にとどまらず，統計結果を 表示できるようになったので, ドットマトリック ス型の表示器が使われている。表示の他, 膜厚值 を顧客へ提示したり，管理用データとして保存す る要求が多くなり，表示之同時にプリンターで印 字できる機能をもったものも市販されている。印 字内容屯膜厚值, 日付, 管理膜厚範囲, 統計結果 等多彩である（図11）。

(1989-1-17 受理)

\section{参考資料}

「陽極酸化皮膜に用いるうず電流式膜厚計に関する 調查」

軽金属製品協会・東京アルミサーフト研究会 